\title{
Brodalumab: a promising option in the management of psoriasis
}

\author{
Melina Infenta Sahay ${ }^{1}$, Roshni Ravindranath ${ }^{1}$, Snehalatha Krishnamoorthy ${ }^{2}$, \\ Damal Kandadai Sriram ${ }^{3}$, Melvin George ${ }^{1 *}$
}

\begin{abstract}
${ }^{1}$ Department of Clinical Research, ${ }^{2}$ Department of Dermatology, ${ }^{3}$ Department of Diabetology, Hindu Mission Hospital, West Tambaram, Chennai, Tamilnadu, India
\end{abstract}

Received: 27 April 2020

Accepted: 06 June 2020

\section{*Correspondence:}

Dr. Melvin George,

Email: drmelvingeorge@hindumissionhospital.org

Copyright: ( $)$ the author(s), publisher and licensee Medip Academy. This is an open-access article distributed under the terms of the Creative Commons Attribution Non-Commercial License, which permits unrestricted non-commercial use, distribution, and reproduction in any medium, provided the original work is properly cited.

\begin{abstract}
Brodalumab, a human monoclonal antibody approved as a biological therapy for treating psoriasis. Due to its consistent results across several clinical studies in treating patients with plaque psoriasis, in 2016 it was first approved worldwide in Japan followed by US FDA approval in 2017 and the European medicines agency. Brodalumab, selectively binds with higher affinity to IL-17RA, thereby blocking the actions of IL-17A, E and F. This act as a novel mechanism to inhibit the inflammation, hyperproliferation, skin thickening and other clinical symptoms associated with psoriasis. The safety and adverse effects of Brodalumab were similar to other IL-17 inhibitors, frequently reported adverse events were nasopharyngitis, neutropenia, and candidiasis. The FDA has recommended a boxed warning for the suicidal tendencies that could occur among Brodalumab users. This review is an endeavor to depict the drug's mode of action, pharmacokinetics, safety, and efficacy as well as its current status among other drugs targeting IL-17.
\end{abstract}

Keywords: Psoriasis, Interlukin-17, Biologics, AMAGINE, Brodalumab

\section{INTRODUCTION}

Psoriasis is a long-term inflammatory illness involving the skin, joints, enthesis, bone, and axial skeleton that is not uncommonly associated with major disability. ${ }^{1} 3 \%$ of the worldwide population suffers from psoriasis and $1 \%$ have psoriatic arthritis. Despite the availability of a large number of therapeutic options for psoriasis, there continues to be a dearth of good control of the disease in a considerable number of patients. ${ }^{2}$ The primary factor in the development and progression of the disease is the irregular function of the immune system. Psoriasis pathogenesis shows connections between $\mathrm{T}$ cells, neutrophils keratinocytes, and dendritic cells. ${ }^{3}$ The immune cells release cytokines in response to genetic and environmental factors, which initiate the inflammation of the disease leading to red, thickened scaly plaques involving multiple areas of the skin surface, including the scalp, elbows, knees, trunk, body folds and genitalia. ${ }^{4}$ Systemic therapy for psoriasis includes phototherapy, retinoids, methotrexate, and cyclosporine. Patients who are intolerant and do not respond to systemic therapies are eligible for treatment with biological therapies. ${ }^{5}$ Some of the anti-tumor necrosis factor (TNF) therapies that have been used in treating psoriasis include adalimumab, and infliximab. ${ }^{3}$ However, the management of the immunosuppressive effects of novel biologic agents continues to exist as a quagmire. Recent developments in understanding the pathogenesis of psoriasis, especially with respect to the inflammatory pathways show that blocking of IL-17 receptors is a crucial target for treating psoriasis. ${ }^{6}$ Currently, several biological agents are targeting the IL-17 pathway which shows promising results in efficacy and safety. This article will review the safety and efficacy of Brodalumab, a human 
immunoglobulin IgG2 monoclonal antibody as a treatment for moderate-to-severe plaque psoriasis.

\section{MECHANISM OF ACTION}

Brodalumab a recombinant, human monoclonal antibody (IgG2) that selectively binds with high affinity to the interleukin 17 receptor A (IL-17R), as IL-17 cytokine plays a vital role in the development of psoriatic plaques. Psoriasis is driven by T-Cell activation associated with the secretion of proinflammatory cytokines, TNF- $\alpha$, interleukin (IL)-17A, IL-22, and interferon IFN- $\gamma$. Studies revealed that skin lesions and blood samples of psoriasis patients contain increased levels of both Th17 cells and IL-17. The IL-17 family is composed of six members (IL-17A to IL-17F). The IL-17A molecule exists as a homodimer of two IL-17A chains or as a heterodimer with IL-17F. ${ }^{8}$ In psoriasis IF-17A and IL-17F act as an etiological factor in the neutrophil chemotaxis by stimulating dendritic cells to release IL-8, CXCL-1, CXCL-3, CXCL-5, and CXCL-6. IL-17 also stimulates fibroblast to produce vascular endothelial growth factor, thus leading to angiogenesis and endothelial cell proliferation. ${ }^{9}$ The IL-17 cytokines exert their effects by targeting five cell surface receptor subunits (IL-17RAIL17RE). Therefore, blocking of IL-17 receptors emerged as a critical target for treating psoriasis. Brodalumab, human monoclonal antibody binds to IL-17RA, thereby blocking the actions of IL-17A, E and F. This acts as a novel mechanism to inhibit the inflammation, hyperproliferation, skin thickening and other clinical symptoms associated with psoriasis..$^{10,11}$

\section{PHARMACOKINETICS}

The pharmacokinetic profile of Brodalumab is similar in patients with psoriasis and healthy individuals. The approved dose range of Brodalumab is $210 \mathrm{mg}$ subcutaneously once a week for patients with psoriasis. The bioavailability of Brodalumab is $54.7 \%$. After a single sc dose, peak drug concentrations were achieved after 3 days of post-injection, were as $\mathrm{C}_{\max }$ was 13.4 $\mathrm{mcg} / \mathrm{ml}$ and AUC were $111 \mathrm{mcg} / \mathrm{ml}$. Brodalumab exhibits non-linear pharmacokinetic properties since it's a monoclonal antibody Brodalumab is expected to be broken down into small peptides and amino acids via catabolic pathways. Based on Brodalumab's population pharmacokinetic modeling, the drug's steady-state volume distribution was approximately $8.9 \mathrm{~L}$ and its clearance is $2.95 \mathrm{~L} /$ day and its mean elimination half-life is approximately 10.9 days. The clearance of the drug was affected by body weight, as body weight increased dose decreased. Whereas age, gender and race did not have any impact on Brodalumab's pharmacokinetics. ${ }^{7,12}$

\section{DOSAGE AND APPLICATION}

Brodalumab is available as prefilled syringes as the approved dose is $210 \mathrm{mg}$ subcutaneously once a week for 3 weeks followed by once in every two weeks. The drug can be injected by self-administration. The patient should be assessed regularly throughout the treatment. After 16 to 20 weeks, if there is no adequate response discontinuing the treatment, is usually recommended. ${ }^{7}$

\section{CLINICAL EFFICACY OF BRODALUMAB}

Across several clinical studies, Brodalumab showed consistent results in treating patients with moderate to severe plaque psoriasis. Here we discuss the major phase III trials of Brodalumab (AMAGINE 1, 2 and 3).

AMAGINE 1 trial was a phase 3, double-blind, placebocontrolled study conducted at multiple centers for a period of up to 52 weeks including induction, withdrawal, and retreatment. 805 patients were screened of which 661 patients with moderate to severe plaque psoriasis (body surface area $(\mathrm{BSA}) \geq 10 \%$, psoriasis area and severity index (PASI) $\geq 12$ and static physician global assistant ( $\mathrm{PPGA} \geq 3$ ) were randomized for a 12 weeks induction phase to receive Brodalumab $210 \mathrm{mg}$ Q2W (222 patients), Brodalumab $140 \mathrm{mg}$ Q2W (219 patients) and placebo 220. At 12 th week patients with sPGA 0 or 1 were rerandomized to either placebo or induction dose. Similarly, after 16 weeks, patients with $\mathrm{sPGA} \geq 3$ have retreated with induction dose. After the retreatment phase, patients with sPGA 2 for $\geq 4$ weeks or sPGA $\geq 3$ were rescued with Brodalumab $210 \mathrm{mg}$ Q2W. PASI 75 was achieved by $83 \%$ in (B-210 mg), $60 \%$ in (B-140 mg) and $3 \%$ in placebo and percentage for sPGA were $75 \%$ $(\mathrm{B}-210 \mathrm{mg}), 54 \%((\mathrm{~B}-140 \mathrm{mg})$ and $1 \%$ placebo, respectively after 12 weeks of treatment. After 52 weeks of treatment, patients who had received B-210 mg achieved PASI 90 by $78 \%$ and PASI 100 by $68 \%$ with an sPGA score of 0 or 1 recorded in $83 \%$. Whereas, group B-140 mg achieved PASI 90/100 in 67\% / 44\% in correspondence with sPGA score of 0 or 1 in $70 \%$ patients. Brodalumab treatment resulted in rapid response, skin clearance and improvement in psoriasis symptoms in patients with moderate to severe plaque psoriasis after 12 weeks and the response was sustained up to 1 year. $^{13}$

AMAGINE-2 and AMAGINE-3 were studies of similar design, namely phase 3 randomized, double-blind, placebo and active-controlled (induction) phase for 12 weeks and maintenance phase to week 52 which compared Brodalumab's efficacy with ustekinumab in psoriasis. It included 1,831 patients in AMAGINE-2, whereas 1,881 patients in AMAGINE-3. For the initial 12 weeks, patients were randomized into four groups in a ratio of 2:2:1:1 (B-210 $\mathrm{mg}$ or B-140 $\mathrm{mg}$ or ustekinumab $45 / 90 \mathrm{mg}$ or placebo). During the maintenance phase, all the patients who were earlier in Brodalumab were again rerandomized to four maintenance groups B-210 mg and B-140 mg (Q2W), B-140 mg every 4 weeks, or B-140 mg every 8 weeks. Patients who were in placebo were switched to receive Brodalumab $210 \mathrm{mg}$ Q2W, whereas patients in the ustekinumab group remained the same. The primary endpoints were compared between 
Brodalumab and placebo with regards to improvement in PASI 75 and sPGA scores at week 12, as well as comparing PASI 100 between Brodalumab and ustekinumab in 12 weeks. In both the studies, Brodalumab showed superiority over ustekinumab and placebo. At week 12, response rates of PASI were considerably high in the Brodalumab group. In AMAGINE-2, PASI 75 was achieved by $86 \%$ in the (B$210 \mathrm{mg}), 67 \%$ in the (B-140 mg) and $8 \%$ in placebo. The percentage of PASI 100 was significantly high in B-210 $\mathrm{mg}(44 \%)$ and ustekinumab (22\%). Similarly, in AMAGINE-3, the response rates of PASI 75(B-210 mg85\%; B-140 mg-69\%; placebo- 6\%) and PASI 100(B-210 mg-37\%; ustekinumab-19\%) were found to be higher in Brodalumab. Concerning the secondary end-points like dermatology life quality index (DLQI) and psoriatic symptom inventory (PSI), Brodalumab showed superiority over placebo and ustekinumab at week 12 . Patients who continued taking Brodalumab 210 every two weeks were able to sustain the PASI rates. ${ }^{14-18}$

A systematic review and network meta- analysis was done to perform a comparative efficacy analysis between brodalumab and other biologic therapies such as apremilast, infliximab, etanercept, adalimumab, secukinumab, and ustekinumab. This included an analysis of 54 studies using the response obtained in PASI 50, 75, 90 and 100. It was found that in all levels of PASI response, the most effective agents showing maximal efficacy were ixekizumab $80 \mathrm{mg}$ Q2W and Brodalumab $210 \mathrm{mg}$ Q2W. The best responses were seen with higher levels of PASI response. The efficacy of $210 \mathrm{mg}$ of brodalumab was much higher than that of most other biologic therapies such as anti-TNF alpha agents, secukinumab, ustekinumab. Apremilast and etanercept had the least response in the network meta-analysis. It is not known if similar results would be seen if health related quality of life would be taken as the outcome instead of PASI score, in the above-mentioned network meta-analysis. ${ }^{19}$

\section{Safety}

A safety assessment of Brodalumab was conducted using available adverse event data from phase II and III clinical trials. The frequently reported adverse events were nasopharyngitis, upper respiratory tract infection, and candidiasis. The safety profile of Brodalumab is similar to other IL-17 antagonists used in treating moderate-tosevere plaque psoriasis. ${ }^{3,12}$

Neutropenia is an important adverse event that must be monitored; IL-17A plays a vital role in the stimulation of granulopoiesis and neutrophil trafficking and hence its inhibition can increase the possibility of getting neutropenia. Crohn's disease was reportedly seen in clinical trials of Brodalumab. ${ }^{10}$ The adverse events seen in patients undergoing treatment for psoriasis are as follows.
Table 1: Common adverse reactions expected with brodalumab.

\begin{tabular}{|ll|}
\hline Adverse reactions & $\begin{array}{l}\text { Brodalumab }(210 \mathrm{mg}) \\
(\%)\end{array}$ \\
\hline Arthralgia & 4.5 \\
\hline Headache & 4.2 \\
\hline Fatigue & 2.3 \\
\hline Diarrhea & 2.1 \\
\hline Oropharyngeal pain & 1.9 \\
\hline Nausea & 1.7 \\
\hline Myalgia & 1.4 \\
\hline Influenza & 1.2 \\
\hline Neutropenia & 1.0 \\
\hline $\begin{array}{l}\text { Tinea infections (tinea } \\
\text { pedis, versicolor) }\end{array}$ & 1.0 \\
\hline
\end{tabular}

Suicidal ideation and behaviour (SIB) events have been seen in phase 2 and 3 clinical studies involving Brodalumab treatment of psoriasis. However, since patients with psoriasis are at increased risk of suicidal behaviour, the events could most likely reflect the impact of the disease on the mind of the patient rather than a drug-induced effect. Such SIB events have also been witnessed in trials seen with other biologic agents. Nevertheless, the US FDA has recommended a boxed warning and has made the sponsor to adopt risk mitigation plans for suicidal tendencies in users of Brodalumab. $^{20}$ Incidence of MACE (major adverse cardiovascular events) has also been reported in Brodalumab treated patients. $^{21}$

\section{CURRENT STATUS OF BRODALUMAB IN PSORIASIS TREATMENT}

Brodalumab has a unique mechanism of IL-17RA blockade, a dose-dependent increase in serum IL-17A has been observed in a few clinical studies. Brodalumab has higher safety and efficacy when compared with the second-generation biologics which targets the IL23/Th17 pathway such as ustekinumab, secukinumab, and ixekizumab. Brodalumab has also shown benefit in treating psoriatic arthritis (PsA), rheumatoid arthritis, and asthma. The drug shows efficacy in patients with or without previous treatment to biologics. It has a low possibility for PK drug-drug interactions given that it is eliminated by an extensive reticuloendothelial clearance mechanism, as a human monoclonal antibody, it is catabolized via intracellular mechanisms following phagocytosis and pinocytosis. ${ }^{22}$

Brodalumab, used for the treatment of moderate-tosevere plaque psoriasis, was first approved worldwide in Japan in July 2016 followed by US FDA on February 16, 2017 and European medicines agency (EMA) on July 2017. 7,12 To date, the Danish Company Leo Pharma has fortunately expanded the geographical rights of Brodalumab and launched it in 18 countries as 
'Kyntheum' in the European Union and as 'Siliq' in other regions through an agreement with Bausch healthcare.

Table 2: Biologics agents approved for the management of psorias.

\begin{tabular}{|c|c|c|c|c|}
\hline Name of the drug & Brodalumab & Ustekinumab & Secukinumab & Ixekizumab \\
\hline Mode of action & $\begin{array}{l}\text { Blocks receptor, } \\
\text { inhibits IL-17A }\end{array}$ & Blocks IL-12 and IL-23 & $\begin{array}{l}\text { Neutralizes IL- } \\
17 \mathrm{~A}\end{array}$ & Neutralizes IL-17A \\
\hline \multirow{2}{*}{$\begin{array}{l}\text { Dose and } \\
\text { frequency }\end{array}$} & \multirow{2}{*}{$\begin{array}{l}\text { Injection } 210 \mathrm{mg} \\
\text { subcutaneously } \\
\text { Q3W, followed by } \\
\text { injection } 210 \mathrm{mg} \\
\mathrm{Q} 2 \mathrm{~W} \text { for a } \\
\text { maximum of } 16 \\
\text { weeks }\end{array}$} & $\begin{array}{l}\text { For patient weighing } \leq 100 \mathrm{~kg} \\
\text { injection } 45 \mathrm{mg} \mathrm{SC} \text { initially and } \\
\text { four weeks later injection } 45 \mathrm{mg} \\
\text { every } 12 \text { weeks. }\end{array}$ & \multirow{2}{*}{$\begin{array}{l}\text { Injection } 300 \\
\text { mg SC Q4W } \\
\text { followed by } \\
\text { injection } 300 \\
\text { mg SC for Q5W }\end{array}$} & \multirow{2}{*}{$\begin{array}{l}\text { Injection } 160 \mathrm{mg} \\
\text { initial dose for } \\
\text { Q2W followed by } \\
\text { injection } 80 \mathrm{mg} \text { for } \\
12 \text { weeks }\end{array}$} \\
\hline & & $\begin{array}{l}\text { For patients weighing } \geq 100 \mathrm{kgs} \text { - } \\
\text { injection } 90 \mathrm{mg} \mathrm{SC} \text { initially and } \\
\text { four weeks later injection } 90 \mathrm{mg} \\
\text { every } 12 \text { weeks }\end{array}$ & & \\
\hline \multirow{7}{*}{$\begin{array}{l}\text { Names of the } \\
\text { major trails }\end{array}$} & AMAGINE-1 & PHOENIX-1 & Feature & Uncover-1 \\
\hline & AMAGINE-2 & PHOENIX-2 & Juncture & Uncover-2 \\
\hline & AMAGINE-3 & PSUMMIT-1 & Erasure & Uncover-3 \\
\hline & AMVISION-1 & \multirow{4}{*}{ PSUMMIT-2 } & Fixture & \multirow{4}{*}{ Uncover-J } \\
\hline & \multirow{3}{*}{ AMVISION-2 } & & Stature & \\
\hline & & & Clear & \\
\hline & & & Sculture & \\
\hline Cost of drug & $\$ 3,500 /$ month & $\$ 1891 /$ month & \$5795/month & \$5950/month \\
\hline
\end{tabular}

Table 3: Details on ongoing trials of Brodalumab.

\begin{tabular}{|c|c|c|c|}
\hline Title & $\begin{array}{l}\text { Treatment } \\
\text { arm/intervention }\end{array}$ & Outcomes & Current status \\
\hline $\begin{array}{l}\text { A study of brodalumab (SILIQ) } \\
\text { with psoriasis participants with } \\
\text { inadequate response to their } \\
\text { current biologic agent regimen } \\
\text { (NCT04149587) }\end{array}$ & $\begin{array}{l}\text { Brodalumab } 210 \mathrm{mg} \\
\text { (SILIQ) }\end{array}$ & $\begin{array}{l}\text { Percentage of PASI } 100 \\
\text { response at week } 26 \text {, followed } \\
\text { by percentage of sPGA, PASI } 75 \\
\text { and } 90 \text { at week } 1,2,4,16 \text { and } 26\end{array}$ & Recruiting \\
\hline $\begin{array}{l}\text { An open-label, single-dose } \\
\text { study to evaluate safety, } \\
\text { tolerability and } \\
\text { pharmacokinetics of } \\
\text { brodalumab in pediatric } \\
\text { subjects (NCT03240809) }\end{array}$ & $\begin{array}{l}\text { Cohort } 1: 12 \text { to }<18 \text { years } \\
\text { (B-140 mg SC dose), Cohort } \\
2: 6 \text { to }<12 \text { years (B-70 mg } \\
\text { SC dose) }\end{array}$ & $\begin{array}{l}\text { Maximum serum concentration } \\
\text { of brodalumab }\end{array}$ & Recruiting \\
\hline $\begin{array}{l}\text { Effect of brodalumab compared } \\
\text { to placebo on vascular } \\
\text { inflammation in moderate-to- } \\
\text { severe psoriasis (NCT03478280) }\end{array}$ & Brodalumab $210 \mathrm{mg} /$ placebo & $\begin{array}{l}\text { To observe aortic wall } \\
\text { inflammation at week } 16 \\
\text { between control group and } \\
\text { placebo, followed by splenic } \\
\text { inflammation, aortic subsegment } \\
\text { and skin inflammation between } \\
\text { two groups }\end{array}$ & Recruiting \\
\hline $\begin{array}{l}\text { Therapeutic drug monitoring of } \\
\text { brodalumab in psoriasis } \\
\text { patients (BIOLOPTIM-BRO) } \\
\text { (NCT04080635) }\end{array}$ & $\begin{array}{l}\text { Single arm treatment } \\
\text { brodalumab } 210 \mathrm{mg}\end{array}$ & $\begin{array}{l}\text { Predictive value of early serum } \\
\text { concentration of brodalumab, } \\
\text { early anti-drug antibody and } \\
\text { therapeutic window of } \\
\text { brodalumab from week } 0 \text { to } 24\end{array}$ & Recruiting \\
\hline \multirow{2}{*}{$\begin{array}{l}\text { Adjusted brodalumab dose } \\
\text { compared with standard } \\
\text { brodalumab dose in subjects } \\
\text { with moderate-to-severe plaque } \\
\text { psoriasis and } \geq 120 \mathrm{~kg} \text { body } \\
\text { weight (ADJUST) } \\
\text { (NCT04306315) }\end{array}$} & $\begin{array}{l}\text { Arm 1: B-210 mg and B-70 } \\
\text { mg }\end{array}$ & \multirow{2}{*}{$\begin{array}{l}\text { Achieving } 90 \% \text { of lower PASI } \\
\text { score at week } 52 \text {, followed by } \\
\text { percentage of sPGA } 0 \text { or } 1 \text { at } \\
\text { week } 40 \text { and week } 52 \text {, PASI } 90 \text {, } \\
\text { BSA and DLQI at week } 52\end{array}$} & \multirow{2}{*}{$\begin{array}{l}\text { Not yet } \\
\text { recruiting }\end{array}$} \\
\hline & $\begin{array}{l}\text { Arm 2: B-210 mg and } \\
\text { placebo }\end{array}$ & & \\
\hline
\end{tabular}


AstraZeneca owns its global trading rights for other Asian countries whereas Kyowa Kirin holds rights for Japan. ${ }^{23}$

\section{CONCLUSION}

Brodalumab is a welcome addition in the battery of biologic therapies that are approved for the treatment of psoriasis. The drug does appear to have incremental efficacy over other established well-known biological therapies for psoriasis. Long term therapy has also shown favorable results with no major adverse events that could cause concern based on the studies done to date. Unlike other biologic agents, the drug does not increase the risk of infections. However, one does have to be wary of the possibility of suicidal ideation and behavior among users of Brodalumab. Real-world studies of Brodalumab will certainly offer more insight into the practical relevance of this drug among patients with moderate to severe psoriasis.

Funding: No funding sources

Conflict of interest: None declared

Ethical approval: Not required

\section{REFERENCES}

1. Goff KL, Karimkhani C, Boyers LN, Weinstock MA, Lott JP, Hay RJ, et al. The global burden of psoriatic skin disease. Br J Dermatol. 2015;172:1665-8.

2. Mease PJ, Genovese MC, Greenwald MW, Ritchlin CT, Beaulieu AD, Deodhar A, et al. Brodalumab, an anti-IL17RA monoclonal antibody, in psoriatic arthritis. New England J Med. 2014;370(24):2295306.

3. Papp KA, Leonardi C, Menter A, Ortonne JP, Krueger JG, Kricorian G, et al. Brodalumab, an antiinterleukin-17 receptor antibody for psoriasis. New England J Med. 2012;366(13):1181-9.

4. Farahnik B, Beroukhim K, Abrouk M, Nakamura M, Zhu TH, Singh R, et al. Brodalumab for the treatment of psoriasis: a review of phase III trials. Dermatology Therapy. 2016;6(2):111-24.

5. Food and Drug Administration. Dermatologic and Ophthalmic Drugs Advisory Committee Meeting Background Package for Bla 761032 Siliq (Brodalumab) Injection, $210 \mathrm{mg} / 15 \mathrm{ml}$. Silver Spring, MD: Food and Drug Administration; 2016.

6. Abuhilal M, Walsh S, Shear N. The role of IL-17 in the pathogenesis of psoriasis and update on IL-17 inhibitors for the treatment of plaque psoriasis. J Cutan Med Surg. 2016;20(6):509-16.

7. Siliq (brodalumab). Bridgewater, NJ: Valeant Pharmaceuticals North America LLC; 2017.

8. Roostaeyan O, Kivelevitch D, Menter A. A review article on brodalumab in the treatment of moderateto-severe plaque psoriasis. Immunotherapy. 2017;9(12):963-78.

9. Blauvelt A, Chiricozzi A. The immunologic role of IL-17 in psoriasis and psoriatic arthritis pathogenesis.
Clinical reviews in allergy and immunology. 2018;55(3):379-90.

10. Roman M, Chiu MW. Spotlight on brodalumab in the treatment of moderate-to-severe plaque psoriasis: design, development, and potential place in therapy. Drug Design Development Therapy. 2017;11:2065.

11. Russell CB, Rand H, Bigler J, Kerkof K, Timour M, Bautista E, et al. Gene expression profiles normalized in psoriatic skin by treatment with brodalumab, a human anti-IL-17 receptor monoclonal antibody. J Immunology. 2014;192(8):3828-36.

12. European Commission, Community register of medicinal products for human use, Kyntheum ${ }^{\circledR}$ (brodalumab); 2017.

13. Papp K, Reich K, Leonardi C, Paul C, Blauvelt A, Baran W, et al. Efficacy and safety of brodalumab in patients with moderate to severe plaque psoriasis: Results of AMAGINE-1, a phase 3, randomized, double-blind, placebo-controlled study through week 12: 275. J Am Academy Dermatology. 2015;72(5).

14. Puig L, Lebwohl M, Bachelez H, Sobell J, Jacobson AA. Long-term efficacy and safety of brodalumab in the treatment of psoriasis: 120-week results from the randomized, double-blind, placebo-and active comparator-controlled phase 3 AMAGINE-2 trial. J Am Academy Dermatology. 2020;82(2):352-9.

15. Strober B, Langley R, Blicharski T, Paul C, Lacour JP, Tyring S, et al. AMAGINE-3: a phase 3 study of efficacy and safety of brodalumab compared with placebo and ustekinumab in moderate to severe plaque psoriasis subjects: 1146. J Am Academy Dermatology. 2015;72(5).

16. Blauvelt A, Papp KA, Lebwohl MG, Green LJ, Hsu $\mathrm{S}$, Bhatt V, et al. Rapid onset of action in patients with moderate-to-severe psoriasis treated with brodalumab: a pooled analysis of data from two phase 3 randomized clinical trials (AMAGINE-2 and AMAGINE-3). J Am Academy Dermatology. 2017;77(2):372-4.

17. Papp KA, Gordon KB, Langley RG, Lebwohl MG, Gottlieb AB, Rastogi $S$, et al. Impact of previous biologic use on the efficacy and safety of brodalumab and ustekinumab in patients with moderate-to-severe plaque psoriasis: integrated analysis of the randomized controlled trials AMAGINE-2 and AMAGINE-3. British J Dermatology. 2018;179(2):320-8.

18. Lebwohl M, Strober B, Menter A, Gordon K, Weglowska J, Puig L, et al. Phase 3 studies comparing brodalumab with ustekinumab in psoriasis. New England J Med. 2015;373(14):131828.

19. Sawyer L, Fotheringham I, Wright E, Yasmeen N, Gibbons C, Moller HA. The comparative efficacy of brodalumab in patients with moderate-to-severe psoriasis: a systematic literature review and network meta-analysis. J Dermatological Treatment. 2018;29(6):557-68.

20. Sallehy RS, Gooderham M, Papp K. Brodalumab: a review of safety. Skin Therapy Lett. 2018;23(2):1-3. 
21. Foulkes AC, Warren RB. Brodalumab in psoriasis: evidence to date and clinical potential. Drugs Context. 2019;8.

22. Papp KA, Reich K, Paul C, Blauvelt A, Baran W, Bolduc $\mathrm{C}$, et al. A prospective phase III, randomized, double-blind, placebo-controlled study of brodalumab in patients with moderate-to-severe plaque psoriasis. British J Dermatology. 2016;175(2):273-86.

23. Parsons L. Leo Pharma to market Astrazenecea's Brodalumab Outside Europe United Kingdoms, PM
Group Worldwide Ltd; 2019. Available at http://www.pmlive.com/pharma_news/leo_pharma_t o_market_astrazenecas_brodalumab_outside_europe 1297.

Cite this article as: Sahay MI, Ravindranath R, Krishnamoorthy S, Sriram DK, George M. Brodalumab: a promising option in the management of psoriasis. Int J Basic Clin Pharmacol 2020;9:11538. 